\title{
Trastuzumab-Associated Flagellate Erythema: Report in a Woman with Metastatic Breast Cancer and Review of Antineoplastic Therapy-Induced Flagellate Dermatoses
}

Philip R. Cohen

To view enhanced content go to www.dermtherapy-open.com

Received: September 13, 2015 / Published online: October 27, 2015

(c) The Author(s) 2015. This article is published with open access at Springerlink.com

\section{ABSTRACT}

Introduction: Flagellate erythema presents as erythematous, individual and intermingled, linear streaks in a whiplash-like pattern. Several conditions, including antineoplastic agents, have been associated with flagellate erythema. A woman with metastatic breast cancer who developed flagellate erythema after receiving trastuzumab is described and the features of flagellate erythema associated with other antineoplastic agents are reviewed.

Methods: PubMed was used to search the following terms, separately and in combination: agent, antineoplastic, bendamustine, bleomycin, breast, cancer, chemotherapy, dermatitis, dermatosis, docetaxel, erythema, flagellate, Herceptin, pigmentation, peplomycin, therapy, and trastuzumab. All papers were reviewed and

Electronic supplementary material The online version of this article (doi:10.1007/s13555-015-0085-2) contains supplementary material, which is available to authorized users.

P. R. Cohen $(\square)$

Department of Dermatology, University of

California San Diego, San Diego, CA, USA

e-mail: mitehead@gmail.com relevant manuscripts, along with their reference citations, were evaluated.

Results: The woman's pruritus and skin lesions promptly resolved after treatment with corticosteroids (oral and topical) and antihistamines (oral); premedication with dexamethasone prior to each subsequent trastuzumab treatment prevented recurrence of flagellate erythema. Chemotherapy-induced flagellate erythema was initially described in oncology patients who received bleomycin. In addition to trastuzumab, other antineoplastic agents that have been associated with the development of flagellate erythema include bendamustine, docetaxel, and peplomycin.

Conclusion: Cutaneous adverse events to trastuzumab are uncommon. However, flagellate erythema should be added to the potential side effects of trastuzumab. In addition, trastuzumab should be added to the list of antineoplastic agents that may be associated with flagellate erythema.

Keywords: Agent;

Antineoplastic; Bendamustine; Bleomycin; Breast cancer; Chemotherapy; Dermatitis; Dermatosis; Docetaxel; Erythema; Flagellate; Herceptin; 
Pigmentation; Peplomycin; Therapy;

Trastuzumab

\section{INTRODUCTION}

Flagellate erythema is a distinctive morphologic presentation of linear, whiplash-like pattern, red streaks on the skin [1]. Trastuzumab (Herceptin ${ }^{\circledR}$; Genentech) is a humanized monoclonal antibody that binds to the human epidermal growth factor receptor 2 (HER2)/neu receptor and has been shown to increase not only overall survival, but also disease-free survival in patients with HER2-positive breast cancer [2, 3]. A woman with trastuzumab-induced flagellate erythema is described and the features of flagellate erythema associated with other antineoplastic agents are reviewed.

PubMed was used to search the following terms, separately and in combination: agent, antineoplastic, bendamustine, bleomycin, breast, cancer, chemotherapy, dermatitis, dermatosis, docetaxel, erythema, flagellate, Herceptin, pigmentation, peplomycin, therapy, and trastuzumab. All papers were reviewed and relevant manuscripts, along with their reference citations, were evaluated. Informed consent was obtained from the patient for being included in the study and for publication of the accompanying images.

\section{CASE REPORT}

A 64-year-old woman presented with left axillary lymphadenopathy in December 2014. Metastatic infiltrating ductal carcinoma of the left breast and left axillary and pectoral lymph nodes was diagnosed. The tumor was clinical stage III T2N2, estrogen receptor negative, progesterone receptor negative, and HER2 overexpressed.
She began treatment in 2015 with triple therapy on February 24, March 17, and April 7: paclitaxel, pertuzumab, and trastuzumab. She also received monotherapy with paclitaxel on March 3, March 10, March 24, and March 31. Following her treatment on April 7, she developed eyelid ptosis and peripheral neuropathy with ataxia that was attributed to paclitaxel.

Monotherapy with trastuzumab was resumed on May 9, 2015. On June 1, 2015, 3 days after receiving trastuzumab on May 29, 2015, she developed pruritus. She also noted a rash developing on her chest, abdomen, arms, and legs.

Cutaneous examination on June 3, 2015 showed erythematous, distinct and intermingled (in a lacy pattern), linear streaks on her arms (Figs. 1, 2), chest, and abdomen (Fig. 3). The morphology of the clinical lesions was a flagellate erythema. Similar linear streaks-both erythematous and hemorrhagic-were also noted on her legs (Figs. 4, 5).

A skin biopsy from her left arm showed basket-weave orthokeratosis overlying a spongiotic epidermis. There was edema in the
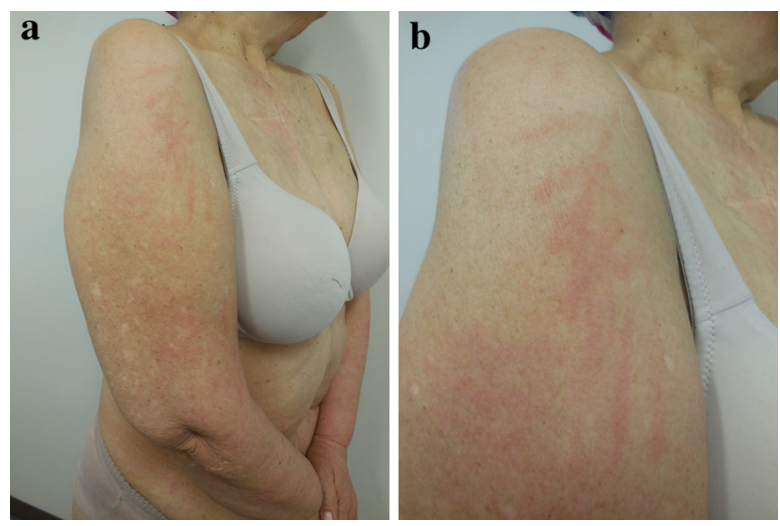

Fig. 1 Distant (a) and closer (b) views of the proximal extensor right arm show flagellate erythema presenting as distinct and intermingled (in a lacy pattern) linear erythematous streaks 

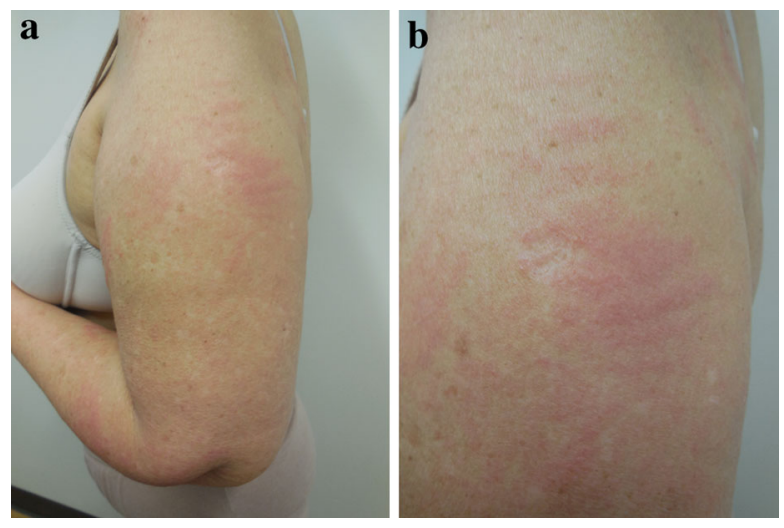

Fig. 2 Distant (a) and closer (b) views of the proximal extensor left arm show flagellate erythema presenting as distinct and intermingled (in a lacy pattern) linear erythematous streaks
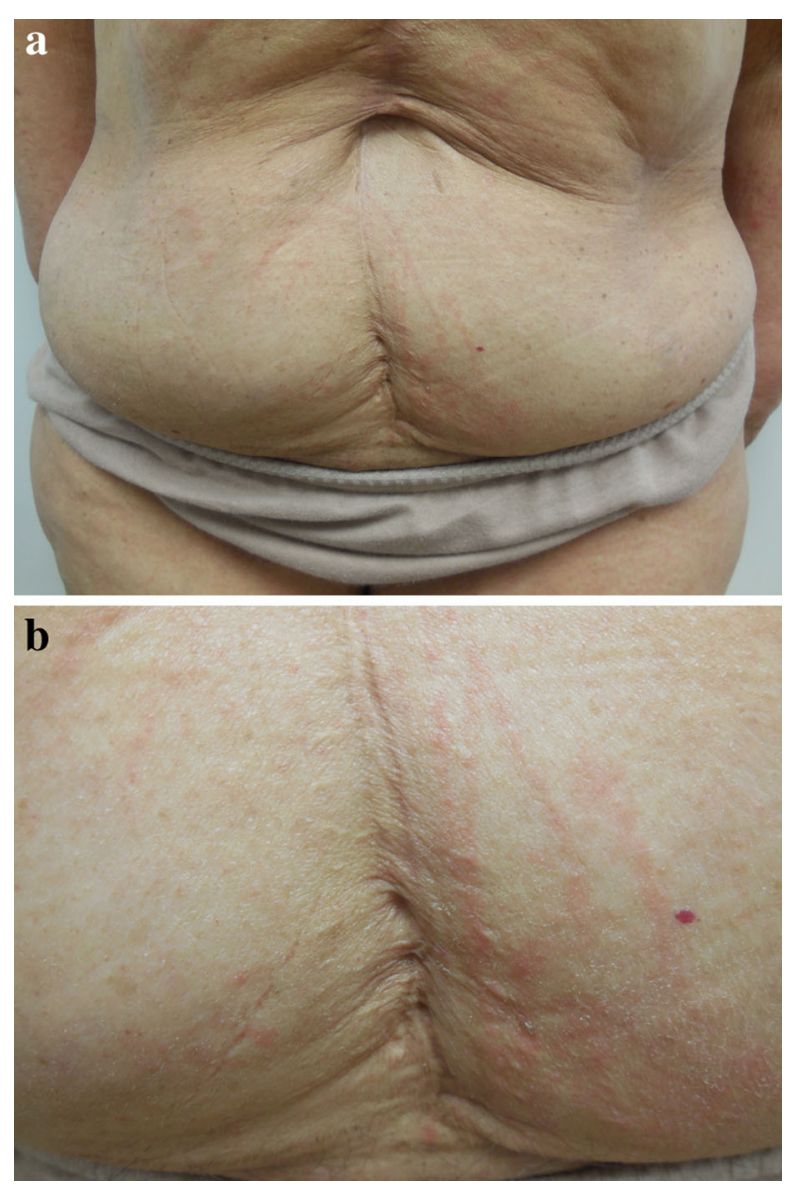

Fig. 3 Distant (a) and closer (b) views of the lower abdomen show flagellate erythema presenting as distinct and intermingled (in a lacy pattern) linear erythematous streaks dermis with a predominantly lymphocytic inflammatory infiltrate that is present around blood vessels in the papillary dermis. There was exocytosis of small lymphocytes into the overlying epidermis (Fig. 6). The pathologic findings were those of a spongiotic dermatitis, compatible with a medication reaction.

Correlation of the clinical history, symptoms and findings in concert with the pathologic features observed established the diagnosis of drug-induced flagellate erythema. In this patient, the causative agent was trastuzumab.

She was treated systemically with prednisone (60 $\mathrm{mg}$ each morning for 3 days, followed by $40 \mathrm{mg}$ each morning for 2 days and $20 \mathrm{mg}$ in the morning for 1 day), and antihistamines for 2 weeks: Fexofenadine $180 \mathrm{mg}$ each morning and diphenhydramine $25 \mathrm{mg}$ each evening. Topical therapy was also initiated: Clobetasol propionate $0.05 \%$ cream twice daily for 10 days and then once daily for 4 days.

Within 2 days, the itching had resolved and the skin eruption had nearly cleared. Follow-up examination after 2 weeks, on June 17, 2015, showed complete clearing of the flagellate erythema on her chest, abdomen, and arms. The erythematous hemorrhagic linear streaks on her distal legs were less prominent and asymptomatic.

The patient has subsequently had a left breast lumpectomy and complete lymph node dissection. There was no residual carcinoma in the breast and 26 lymph nodes were negative for malignancy. She has also received adjuvant radiation therapy.

Her oncologist decided that she would need to receive treatment with trastuzumab, every 3 weeks, for 1 year. She has been receiving dexamethasone prior to each trastuzumab treatment to prevent recurrence of the adverse skin event. Neither pruritus nor flagellate 

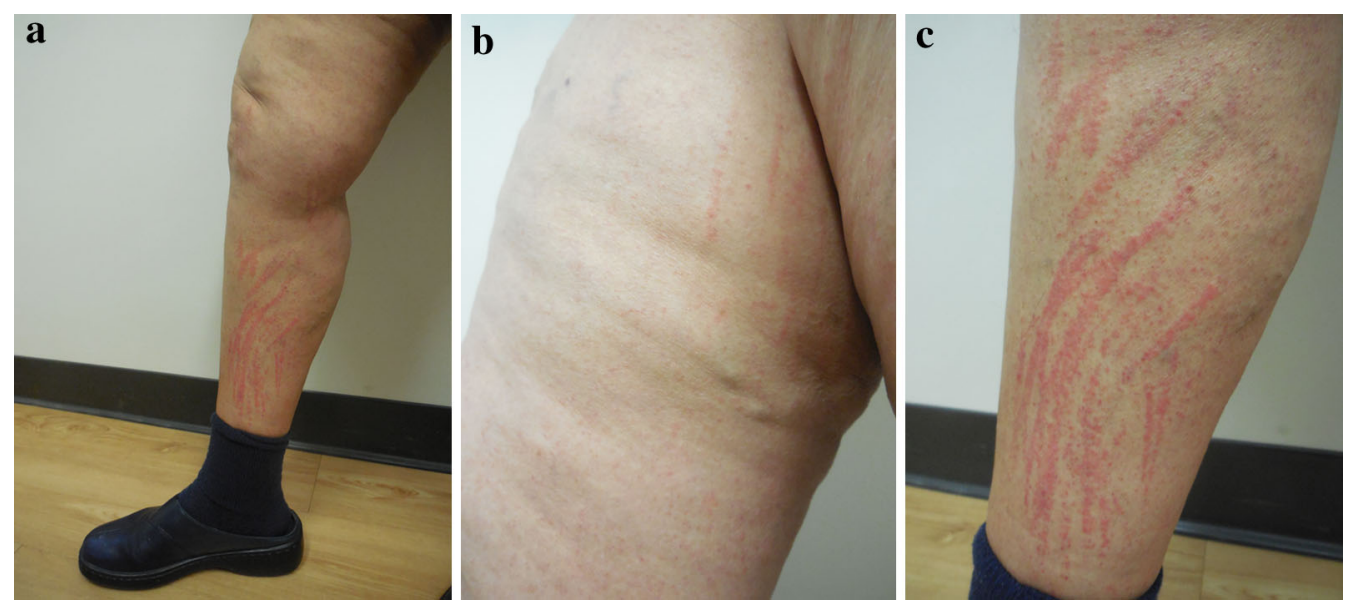

Fig. 4 Distant (a) view of the right leg and closer views of the right medial thigh (b) and right medial distal leg (c) show flagellate erythema presenting as erythematous and hemorrhagic linear streaks
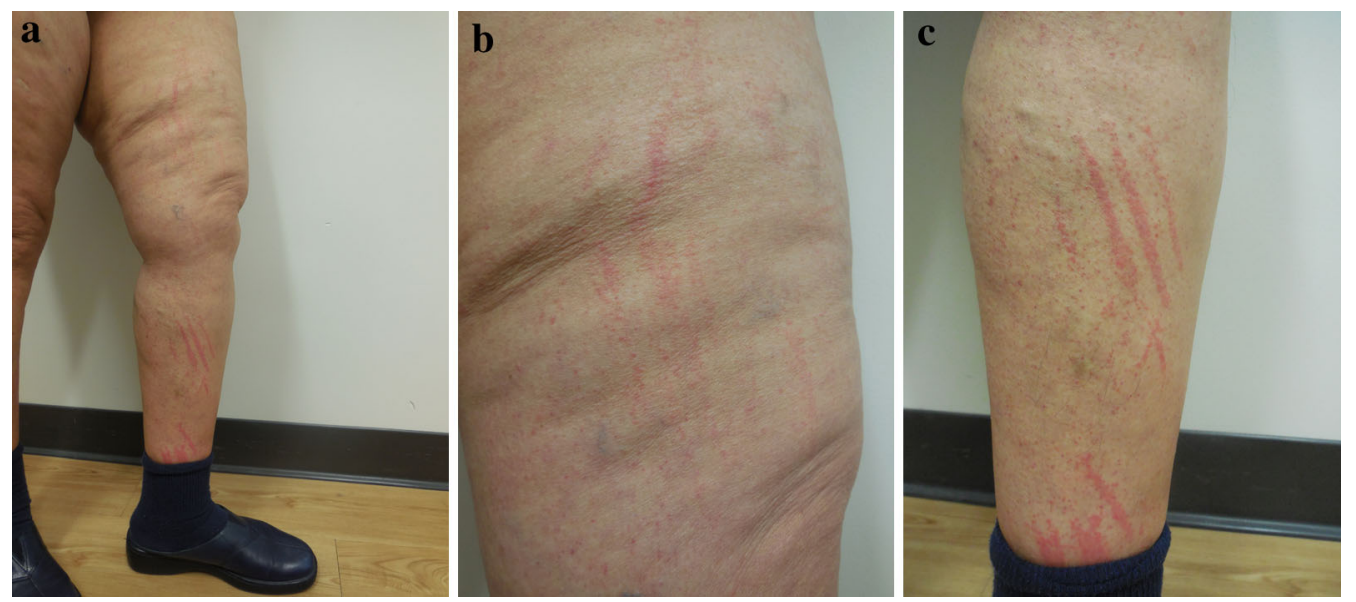

Fig. 5 Distant (a) view of the left leg and closer views of the left anterior thigh (b) and left medial distal leg (c) show flagellate erythema presenting as erythematous and hemorrhagic linear streaks

erythema has occurred with the subsequent administration of trastuzumab.

\section{DISCUSSION}

The individual flagellate dermatoses may be referred to as flagellate erythema or flagellate dermatitis or both (Table 1) [1, 4-42]. Flagellate erythema has a unique clinical presentation. It has an intermingled lacy pattern-similar to multiple adjacent flagella; indeed, the morphology of the cutaneous eruption is suggestive of the individual having been whipped. The lesions often are red and macular at presentation. Dermatitis may develop with progression to raised linear plaques. Residual patterned postinflammatory hyperpigmentation may subsequently persist [1].

Antineoplastic agents have also been observed to cause flagellate dermatoses. They include not only bleomycin [5-13], but also bendamustine [4], docetaxel [14], peplomycin $[15,16]$ and trastuzumab (current report) (Table 2) [4-16]. 


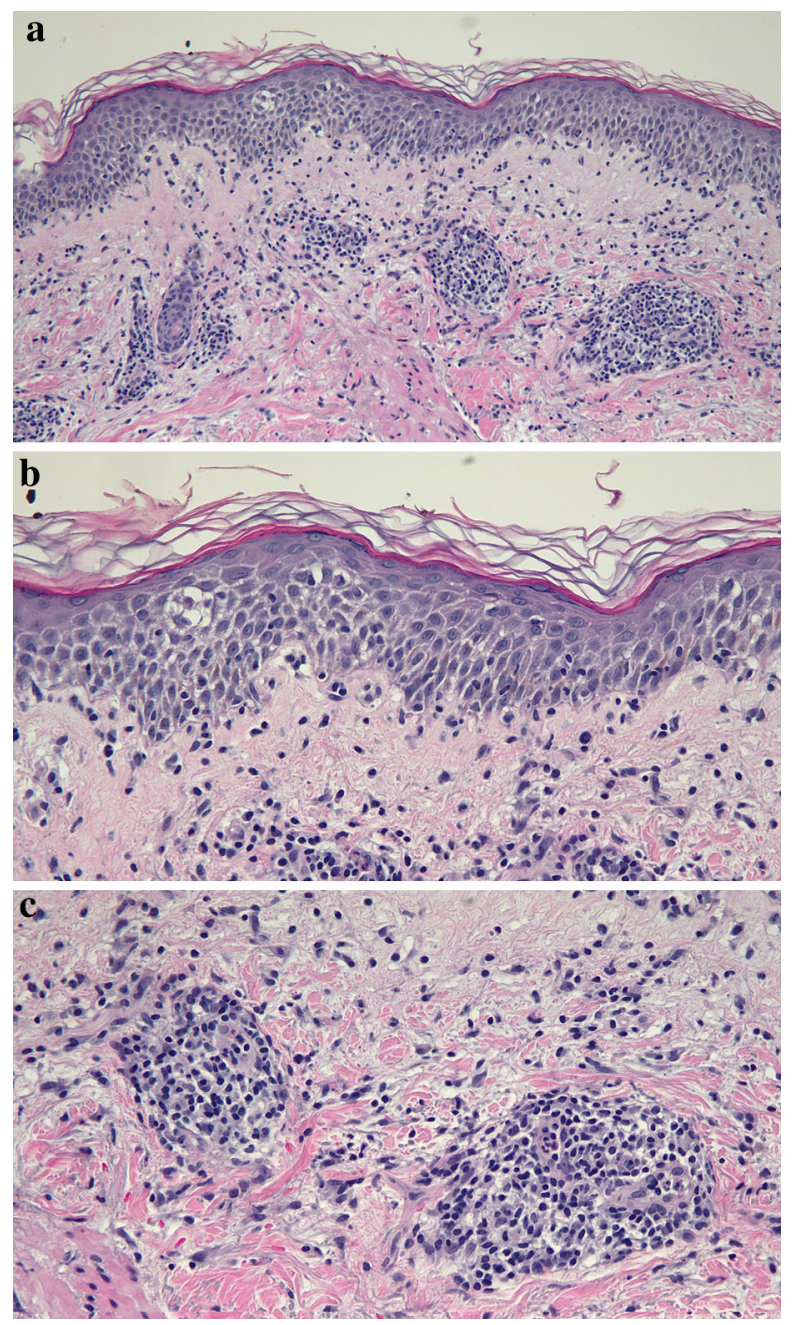

Fig. 6 Distant (a) and closer (b, c) views of a biopsy from the flagellate erythema on the left arm shows orthokeratosis (a, b), spongiosis (a, b), edema in the upper dermis $(\mathbf{a}, \mathbf{b}$ and $\mathbf{c}$ ), and perivascular lymphocytic inflammation (a, c) with exocytosis of lymphocytes into the epidermis (a, b) [hematoxylin and eosin; $\mathbf{a}=10 \times ; \mathbf{b}=20 \times ; \mathbf{c}=20 \times$ ]

Antineoplastic therapy-associated flagellate erythema was initially described in oncology patients who received bleomycin by Moulin in 1970 [10, 43, 44]. Bleomycin, a chemotherapeutic antibiotic isolated from the soil fungus Streptomyces verticillus, inhibits the uptake of thymidine and thereby resulting in fragmentation of DNA [7, 10, 43]. The adverse reaction has been observed in patients with Hodgkins lymphoma [10-13], and germ cell tumors in both men [5-7] and women [8, 9]. The eruption is often associated with generalized pruritus and has a predilection to occur over bony prominence $[7-9,11,12]$. The erythematous flagellate streaks subsequently develop into hyperpigmented whiplash-like lines. It has been postulated that this unique cutaneous adverse event for bleomycin occurs since the bleomycin hydroxylase enzyme that metabolizes the drug is not found in the skin, allowing the drug to accumulate and cause toxicity. Another hypothesis is that minor trauma to the skin, such as scratches or pressure over bony prominences, results in increased blood flow and accumulation of the drug at these sites [10].

The clinical presentation of bleomycin-associated flagellate erythema is distinctively characteristic; hence, the diagnosis is often established based on the morphologic presentation. When a biopsy has been performed, the findings are variable. They have included fixed drug eruption, hypersensitivity reaction (systemic or urticarial), inflammatory oncotaxis, lymphocytic vasculitis, and perivascular dermatitis with eosinophils [7, 10, 12, 13].

Treatment of bleomycin-induced flagellate erythema typically involves discontinuing the drug; in addition, treatment with antihistamines (oral) and corticosteroids (oral and/or topical) may be initiated. The symptoms and dermatosis typically resolve rapidly. However, residual postinflammatory hyperpigmentation may persist $[6-8,10]$.

Bleomycin-induced flagellate erythema may not be a therapy-limiting side effect [9]. However, the drug is usually discontinued in patients who develop severe rash [12, 13]. Also, since the overall success of treatment in patients with Hodgkin's lymphoma is not influenced by the exclusion of bleomycin in patients initially 
Table 1 Flagellate dermatoses

Antineoplastic therapy-induced erythema/dermatitis

Bendamustine [4]

Bleomycin [5-13]

Docetaxel [14]

Peplomycin $[15,16]$

Trastuzumab [current report]

Hypereosinophilia syndrome [17]

Idiopathic

Idiopathic flagellate pigmentation [18]

Infectious diseases

Chikungunya fever $[19,20]$

Parvovirus B19 [21]

Infliction-associated lesions [1, 22, 23]

Abuse

Child

Elder

Partner

Self (dermatitis artefacta)

Pleasure

Sexual (sadomasochism)

Punishment

Religious discipline

Torture

Pruritus-related dermatoses [1]

Dermatitis

Allergic contact dermatitis (rhus antigen related)

Phytophotodermatitis (lime associated)

Dermatographism

Excoriations

Rheumatologic conditions

Adult onset Still's disease [24-28]

Dermatomyositis [29-34]

Systemic lupus erythematosus [35]
Table 1 continued

Toxin-induced conditions

Mushroom-related

Boletus (porcini-grilled) [36]

Shiitake (raw or undercooked) [37-40]

Organism-related

Cnidarian (Portuguese man-of-war and jelly fish)

stings [41, 42]

Paederus (Rove beetles) and other insects [1]

treated with bleomycin-containing regimens, the drug is often subsequently avoided in oncology patients who experience bleomycin-induced flagellate erythema $[12,13]$.

Bendamustine, a unique multifunctional alkylating agent that crosslinks DNA and produces single-strand and double-strand breaks, is given intravenously typically at a dose of $100 \mathrm{mg}$ per meter square on days 1 and 2 of a 28-day cycle for chronic lymphocytic leukemia [45]. A 53-year-old man with chemotherapy and radiation therapy refractory transformed chronic lymphocytic leukemia (Richter's syndrome) developed linear pruritic red patches, papules and plaques on his arms, legs, trunk and back a few days after starting the second cycle of bendamustine and rituximab. The chemotherapy was discontinued and topical corticosteroid ointment (triamcinolone $0.1 \%)$ was applied twice daily. The symptoms ceased within a few days and the cutaneous eruption resolved with postinflammatory hyperpigmentation [4].

Docetaxel (Taxotere ${ }^{\circledR}$; Aventis Pharma S.A.) is an antimicrotubule agent that has been used intravenously to treat solid tumors including breast, gastric, non-small-cell lung, ovarian, and prostate cancer [46]. Cutaneous adverse effects 
Table 2 Antineoplastic therapy-induced flagellate erythema/dermatitis

\begin{tabular}{|c|c|c|c|c|c|c|c|c|}
\hline Drug & Cancer & Dose & $\mathbf{P}$ & $\begin{array}{l}\text { Onset of } \\
\text { rash }\end{array}$ & Path & Treatment & Comment & References \\
\hline Bendamustine & CLL & NS & + & $\mathrm{C} 2 \mathrm{D} 2+$ & {$[\mathrm{a}]$} & $\begin{array}{l}\mathrm{D} / \mathrm{c} \text { drug; TAC } \\
\text { oint }\end{array}$ & [b] Rapidly improved & {$[4]$} \\
\hline Bleomycin & $\begin{array}{c}\text { GCT, } \\
\text { HL }\end{array}$ & $\begin{array}{l}5 \mathrm{IU} \text { to } \\
\quad 465 \mathrm{IU}\end{array}$ & + & $\begin{array}{r}<1 \text { day to } \\
9 \text { weeks }\end{array}$ & {$[c]$} & {$[\mathrm{d}]$} & {$[\mathrm{e}]$} & {$[5-13]$} \\
\hline Docetaxol & Breast & NS & + & $\mathrm{C} 2 \mathrm{D} 4$ & NP & None $[\mathrm{f}]$ & {$[\mathrm{g}]$} & {$[14]$} \\
\hline Peplomycin & SCC & $?$ & $?$ & NS & NS & NS & {$[\mathrm{h}]$} & {$[15,16]$} \\
\hline Trastuzumab & Breast & $\begin{array}{l}6 \mathrm{mg} \text { per } \\
\mathrm{kg}\end{array}$ & + & C5D4 & {$[\mathrm{i}]$} & $\begin{array}{l}\text { Steroid and } \\
\text { antihistamine }[\mathrm{j}]\end{array}$ & $\begin{array}{l}\text { Dexa to prevent } \\
\text { recurrence }[\mathrm{k}]\end{array}$ & $\mathrm{CR}$ \\
\hline
\end{tabular}

$C 2 D 2+$ A few days after the second cycle, C2D4 3 days after the second cycle, C5D4 3 days after receiving the fifth cycle, $C L L$ chronic lymphocytic leukemia, $C R$ current report, Dexa Dexamethasone, D/c Stop, GCT germ cell tumor, $H L$ Hodgkin's lymphoma, $I U$ International units, $N P$ not performed, $N S$ not stated, Path pathology, $P$ pruritus, $S C C$ squamous cell carcinoma, TAC oint Triamcinolone $0.1 \%$ ointment twice daily, + present, ? unavailable

[a] Pathology showed perivascular lymphocytes, plasma cells and scattered eosinophils with minimal epidermal change

[b] Within a few days, the eruption as well as the itching started to improve. At the site of the previous linear red patches, the patient developed digitate postinflammatory hyperpigmented patches

[c] Pathology is variable including fixed drug eruption, hypersensitivity reaction (systemic or urticarial), inflammatory oncotaxis, lymphocytic vasculitis, and perivascular dermatitis with eosinophils

[d] Most affected individuals stop drug [12, 13]; however, bleomycin-induced flagellate erythema may not be a therapy-limiting side effect in all patients [9]. Topical and/or oral corticosteroids, with or without oral antihistamines, are used

[e] The eruption is typically self-limited; it resolves within several weeks to months. The subsequent hyperpigmentation can be permanent ( 6 months or longer). There are individual reports of treating the hyperpigmentation with either intense pulse light therapy or non-ablative laser

[f] The itch and erythema settled spontaneously, with gradual resolution of the pigmentation over weeks

$[\mathrm{g}]$ The investigators postulated that corticosteroid treatment suppressed the flagellate erythema since the symptoms and rash appeared only after discontinuation of the dexamethasone

[h] Five of 23 patients developed an "eruption with skin excoriations or pigmentation along scratch dermatitis [16]."

[i] Pathology showed dermal edema and perivascular lymphocytes with exocytosis of lymphocytes into the overlying spongiotic epidermis

[j] Oral prednisone for 6 days (60 $\mathrm{mg}$ for 3 days, then $40 \mathrm{mg}$ for 2 days and then $20 \mathrm{mg}$ for 1 day), oral antihistamines for 2 weeks (fexofenadine $180 \mathrm{mg}$ each morning and diphenhydramine $25 \mathrm{mg}$ each evening), and topical clobetasol propionate $0.05 \%$ cream (twice daily for 10 days and then once daily for 4 days)

$[\mathrm{k}]$ The patient has been premedicated with dexamethasone prior to receiving each subsequent trastuzumab treatment and there has been no recurrence of trastuzumab-associated pruritus or flagellate erythema

include acral erythema (also referred to as hand-foot syndrome), photodermatoses (including subacute lupus erythematosus), and hemorrhage of the nail plates [46-48]. A 58-year-old woman with metastatic breast cancer developed pruritic linear erythematous hyperpigmented streaks on her central back and flanks 3 days after her second intravenous course of docetaxel; the onset of her rash occurred with the conclusion of 3 days of oral dexamethasone that is routinely given to prevent hypersensitivity reactions and fluid retention from the docetaxel. There was spontaneous resolution of her itch and 
erythema; the hyperpigmentation gradually resolved over the following weeks [14].

Peplomycin, an analog of bleomycin that was discovered by Professor Hamao Umezawa, has been administered intravenously for treatment of breast cancer, Hodgkin's lymphoma, prostate cancer, and squamous cell carcinoma of the cervix, head and neck, and skin [49]. Combination chemotherapyconsisting of cisplatin, vincristine, and peplomycin-was given to 23 Japanese patients with squamous cell carcinoma. The peplomycin was either administered by continuous intravenous infusion or continuous subcutaneous infusion (using a microinfustion pump). Five of the patients developed an "eruption with skin excoriations or pigmentation along scratch dermatitis [16]."

Trastuzumab (Herceptin) is a human monoclonal antibody. It binds selectively and with high affinity to the extracellular domain of the HER2/neu receptor. Treatment with trastuzumab increases survival, in both the metastatic and the adjuvant setting, of patients with HER2-positive breast cancer; the sooner trastuzumab is initiated, the greater its potential benefit. The agent is administered intravenously, as monotherapy or in combination with chemotherapy, usually every 3 weeks $(8 \mathrm{mg} / \mathrm{kg}$ followed by $6 \mathrm{mg} / \mathrm{kg}$ ) for 12 months [2, 3, 50, 51].

Cutaneous adverse reactions to trastuzumab are rare (Table 3) [50-59]. Tufted hair folliculitis was observed in one woman who received monotherapy with trastuzumab [59]; also, albeit uncommon, rash associated with a serious infusion reaction was noted in less than $0.3 \%$ of patients [52]. Combination of trastuzumab and chemotherapy resulted in an increase of mild to moderate signs and symptoms of infusion reactions compared to patients receiving chemotherapy alone [53]. Photosensitivity was described in two women; however, in addition to trastuzumab, they were also receiving a taxane to which the skin reaction was likely caused $[57,58$, $60]$. In contrast to other investigators, a study of 51 Japanese women with metastatic breast cancer who underwent trastuzumab-containing chemotherapy observed both skin (49\%) and nail (27.5\%) toxicity; however, these adverse events may have been secondary-in part or in total-to the concurrent chemotherapy [56]. The incidence or severity of acute radiation-associated skin toxicity was not increased in women who received concomitant trastuzumab and radiation therapy $[50,51]$.

Trastuzumab-associated flagellate erythema, to the best of my knowledge, has not previously been described. The described patient had erythematous, distinct and intermingled (lacy) linear plaques; her pathology findings showed dermatitis. Her pruritic lesions promptly resolved, without postinflammatory hyperpigmentation, after corticosteroid (oral and topical) and antihistamine (oral) treatment.

Trastuzumab was an integral component of the reported patient's tumor treatment. In contrast to patients with bleomycin-induced flagellate erythema in whom the drug is usually discontinued, she continued to receive trastuzumab and was premedicated with dexamethasone prior to each subsequent treatment. With this management, there was no recurrence of the flagellate erythema when she received subsequent doses of trastuzumab.

\section{CONCLUSIONS}

Flagellate erythema is a distinctive morphologic reaction pattern. Chemotherapy-associated flagellate erythema was initially observed in oncology patients treated with bleomycin. However, flagellate erythema has subsequently been observed with other antineoplastic agents, 
Table 3 Cutaneous adverse reactions in patients receiving trastuzumab

\begin{tabular}{|c|c|c|}
\hline Reaction & Comments & Ref \\
\hline $\begin{array}{l}\text { XRT skin } \\
\text { reactions }\end{array}$ & $\begin{array}{l}\text { Adverse events included radiation therapy-associated acute skin toxicity (dermatitis) and late } \\
\text { skin reactions (telangiectasias, local pain, and fibrosis) [a] }\end{array}$ & {$[50,51]$} \\
\hline $\begin{array}{l}\text { Flagellate } \\
\text { erythema }\end{array}$ & $\begin{array}{l}\text { A 64-year-old woman with breast cancer developed pruritus and linear erythematous streaks of } \\
\text { flagellate erythema on her arms, chest, abdomen, and legs } 3 \text { days after receiving her fifth } \\
\text { cycle of trastuzumab. She was treated with corticosteroids (oral and topical) and } \\
\text { antihistamines (oral); symptoms resolved within } 2 \text { days and there was clearing of the lesions } \\
\text { on her arms, chest and abdomen within } 2 \text { weeks. Premedication with dexamethasone prior } \\
\text { to each subsequent trastuzumab treatment successfully prevented recurrence of flagellate } \\
\text { erythema }\end{array}$ & CR \\
\hline
\end{tabular}

Infusion

reaction

Nail toxicity

Photosensitivity

Skin toxicity

Tufted hair

folliculitis
These occur in $30-40 \%$ of patients, usually present as chills or fever, with the first infusion; they occur only in $3-5 \%$ of patients with subsequent infusions. Severe infusion reactions are uncommon (about $0.3 \%$ ) and may include rash

In a group of 51 patients, nail toxicity included softening, thinning, or loss (13 patients), paronychia (4 patients) and discoloration (2 patients) [b]

with aberrations in porphyrin biosynthesis while receiving concurrent taxane and trastuzumab therapy; the lesions resolved and the porphyrins normalized following taxane withdrawal: a 40-year-old woman, following treatment with paclitaxel and trastuzumab, presented with photodistributed erythema multiforme and onycholysis [57] and a 63-year-old woman, receiving treatment with docetaxel and trastuzumab, presented with photodistributed dermatitis consisting of erythematous patches on her hands and face and widespread papules and pustules on her scalp after sun exposure [58] [c]

In a group of 51 patients, skin toxicity included eruptions on the face and body (14 patients), skin detachment or thinning on hands and feet (9 patients) itching (8 patients) and skin drying (7 patients) $[\mathrm{b}]$

A 47-year-old woman with breast cancer had significant hair loss after treatment with doxorubicin and cyclophosphamide. During treatment with trastuzumab, she noted scalp hair regrowth. However, she also experienced scaling and pruritus of her scalp. Examination of the scalp showed perifollicular erythema and hyperkeratosis. In a patch of alopecia, a few scattered central and peripheral tufts of hair were noted. Tufts of 3-8 hair shafts emerging from dilated follicular openings were observed with dermoscopy. These findings established a diagnosis of tufted hair folliculitis. There was complete resolution of the scalp scaling and itching following twice daily treatment with clobetasol propionate $0.05 \%$ topical solution

$C R$ current report, $X R T$ radiation therapy

[a] Concurrent trastuzumab and adjuvant breast radiotherapy did not increase adverse events associated with radiotherapy [b] In a retrospective study of 51 Japanese patients with breast cancer who underwent trastuzumab-containing chemotherapy, 27 patients had skin and/or nail toxicity: 13 patients had only skin toxicity, 12 patients had both skin and nail toxicity, and 2 patients had only nail toxicity. However, some of the observations-in part or in total-may be attributed to the concurrent chemotherapy the patients were receiving

[c] In both women, the acquired photosensitivity is likely to be secondary to the taxane they were receiving and not caused by the trastuzumab 
including bendamustine, docetaxel, and peplomycin. A woman with metastatic breast cancer developed flagellate erythema after receiving trastuzumab. Her lesion promptly responded to treatment with corticosteroids (oral and topical) and systemic antihistamines. The adverse cutaneous reaction was subsequently prevented by premedicating her with dexamethasone prior to each future treatment of trastuzumab. In conclusion, trastuzumab should be added to the list of potential etiologies associated with flagellate erythema and flagellate erythema should also be included in the potential adverse events that can be caused by trastuzumab.

\section{ACKNOWLEDGMENTS}

No funding or sponsorship was received for this study or publication of this article. The named author meets the International Committee of Medical Journal Editors (ICMJE) criteria for authorship for this manuscript, takes responsibility for the integrity of the work as a whole, and has given final approval for the version to be published.

Disclosures. Dr. Cohen has nothing to disclose.

Compliance with ethics guidelines. Informed consent was obtained from the patient for being included in the study and for publication of the accompanying images.

Open Access. This article is distributed under the terms of the Creative Commons Attribution-NonCommercial 4.0 International License (http://creativecommons.org/licenses/ by-nc/4.0/), which permits any noncommercial use, distribution, and reproduction in any medium, provided you give appropriate credit to the original author(s) and the source, provide a link to the Creative Commons license, and indicate if changes were made.

\section{REFERENCES}

1. Bhushan P, Manjul P, Baliyan V. Flagellate dermatoses. Indian J Dermatol Venereol Leprol. 2014;80:149-52.

2. Brollo J, Curigliano G, Disalvatore D, Marrone BF, Criscitiello C, Bagnardi V, Kneubil MC, Fumagalli L, Locatelli M, Manunta S, Goldhirsch A. Adjuvant trastuzumab in elderly with HER-2 positive breast cancer: a systematic review of randomized controlled trials. Cancer Treat Rev. 2013;39:44-50.

3. Iwata H. Perspective of trastuzumab treatment. Breast Cancer. 2007;14:150-5.

4. Mahmoud BH, Eide MJ. Bendamustine-induced "flagellate dermatitis". Dermatol Online J. 2012;18(11):12.

5. Changal KH, Raina $\mathrm{H}$, Changal QH, Raina M: Bleomycin-induced flagellate erythema: a rare and unique drug rash. West Indian Med J 2014;63(7):807-9.

6. Lu CC, Lu YY, Wang QR, Wu CH. Bleomycin-induced flagellate erythema. Balkan Med J. 2014;31:189-90.

7. Lee HY, Kim KH, Ryu Y, Song SY. Bleomycin-induced flagellate erythema: a case report and review of the literature. Oncol Lett. 2014;8:933-5.

8. Khmamouche MR, Debbagh A, Mahfoud T, Aassab R, Lkhoyaali S, Ichou M, Errihani H. Flagellate erythema secondary to bleomycin: a new case report and review of the literature. J Drug Dermatol. 2014;13:983-4.

9. Eungdamrong J, McLellan B. Flagellate erythema. Dermatol Online J. 2013;19(12):20716.

10. Mota GD, Penna AM, Soares RC, Baiocchi OC. Bleomycin-induced flagellate dermatitis. Rev Bras Hematol Hemoter. 2014;38:297-9.

11. Vennepureddy A, Siddique MN, Odaimi M, Terjanian T: Bleomycin-induced flagellate erythema in a patient with Hodgkin's lymphoma-a case report and review of the literature. J Oncol Pharm Pract (2015) Apr 8 [Epub ahead of print]. 
12. Biswas A, Chaudhari PB, Sharma P, Singh L, Julka PK, Sethuraman G. Bleomycin induced flagellate erythema: revisiting a unique complication. J Cancer Res Ther. 2013;9:500-3.

13. Chen YB, Rahemtullah A, Breeden E, Hochberg EP. Bleomycin-induced flagellate erythema. J Clin Oncol. 2007;25:898-900.

14. Tallon B, Lamb S. Flagellate erythema induced by docetaxel. Clin Exp Dermatol. 2008;33:276-7.

15. Yamamoto T, Nishioka K. Flagellate erythema. Int J Dermatol. 2008;45:627-31.

16. Araki Y, Tamura K, Seita M. Side effects of peplomycin. Gan To Kagaku Ryoho. 1986;13:2446-50.

17. May LP, Kelly J, Sanchez M. Hypereosinophilic syndrome with unusual cutaneous manifestations in two men with HIV infection. J Am Acad Dermatol. 1990;23:202-4.

18. Pise GP, Vetrichevvel TP, Thappa DM. Idiopathic flagellate pigmentation. Indian $\mathrm{J}$ Dermatol. 2007;52:117-8.

19. Kandhari R, Khunger N, Singh A. Flagellate pigmentation and exacerbation of melasma following chikungunya fever: a less frequently reported finding. Indian J Dermatol Venereol Leprol. 2012;78:774.

20. Riyaz N, Riyaz A, Rahima, Abdul Latheef EN, Anitha PM, Aravindan KP, Nair AS, Shameera P. Cutaneous manifestations of chikungunya during a recent epidemic in Calicut, north Kerala, south India. Indian J Dermatol Venereol Leprol. 2010;76:671-6.

21. Miguelez A, Duenas J, Hervas D, Hervas JA, Salva F, Martin-Santiago A. Flagellate erythema in parvovirus B19 infection. Int J Dermatol. 2014;53:e583-5.

22. Cohen PR. Hydroxychloroquin-associated hyperpigmentation mimicking elder abuse. Dermatol Ther (Heidelb). 2013;3:203-10.

23. Danesh MJ, Chang AL. The role of the dermatologist in detecting elder abuse and neglect. J Am Acad Dermatol. 2015;73:285-93.

24. Kikuchi N, Satoh M, Ohtsuka M, Yamamoto T. Persistent pruritic papules and plaques associated with adult-onset Still's disease: report of six cases. J Dermatol. 2014;41:407-10.

25. Ciliberto H, Kumar MG, Musiek A. Flagellate erythema in a patient with fever. JAMA Dermatol. 2013;149:1425-6.

26. Suzuki K, Kimura Y, Aoki M, Takezaki S, Tuchida T, Takano T, Kawana S. Persistent plaques and linear pigmentation in adult-onset Still's disease. Dermatology. 2001;202:333-5.

27. Fujii K, Konishi K, Kanno Y, Ohgou N. Persistent generalized erythema in adult-onset Still's disease. Int J Dermatol. 2003;42:824-5.

28. Sun NZ, Brezinski EA, Berliner J, Haemel A, Connolly MK, Gensler L, McCalmont TH, McCalmont TH, Shinkai K. Updates in adult-onset Still disease: atypical cutaneous manifestations and associations with delayed malignancy. J Am Acad Dermatol. 2015;73:294-303.

29. Molina-Ruiz AM. Romero F, Carrasco L, Feltes F, Haro R, Requena L: Amyophatic dermtomyositis presenting as a flagellate skin eruption with positive MDA5 antibodies and thyroid cancer: a real association? Clin Exp Dermatol (2015). doi:10. 1111/ced.12674.

30. Ito $\mathrm{K}$, Imafuku S, Hamaguchi $\mathrm{Y}$, Fujimoto $\mathrm{M}$, Nakayama J. Case report of anti-transcription intermediary factor-1-gamma/alpha antibody-positive dermatomyositis associated with gastric cancer and immunoglobulin G4-positive pulmonary inflammatory pseudotumor. J Dermatol. 2013;40:587-9.

31. Schulman JM, McCalmont TH, Shinkai K. Fulminant dermatomyositis with flagellate erythema. J Drugs Dermatol. 2011;10:902-4.

32. Kaji K, Fujimoto M, Hasegawa M, Kondo M, Saito Y, Komura K, Matsushita T, Orito H, Hamaguchi Y, Yanaba K, Itoh M, Asano Y, Seishima M, Ogawa F, Sato S, Takehara K. Identification of a novel autoantibody reactive with 155 and $140 \mathrm{kDa}$ nuclear proteins in patients with dermatomyositis: an association with malignancy. Rheumatology (Oxford). 2007;45:627-31.

33. Parodi A, Caproni M, Marzano AV, DeSimone C, LaPlace M, Quaglino P, Veller Fornasa C, Zane C, Vaccaro M, Papini M, Fabbri P, Rebora A. Dermatomyositis in 132 patients with different subtypes: cutaneous signs, constitutional symptoms and circulating antibodies. Acta Derm Venereol. 2002;82:48-51.

34. Kimyai-Asadi A, Tausk FA, Nousari HC. A patient with dermatomyositis and linear streaks on the back. Centripetal flagellate erythema (CFE) associated with dermatomyositis. Arch Dermatol. 2000;136(667):670.

35. Niyama S, Katsuoka K. Systemic lupus erythematosus with flagellate erythema. Eur J Dermatol. 2012;22:808-9.

36. Molin S, Summer B, Thomas P, Letule V, Ruzicka T, Rueff F, Herzinger T. Boletus dermatitis: a new 
variant of flagellate erythema. Ann Allergy Asthma Immunol. 2015;115:254-5.

37. Boels D, Landreau A, Bruneau C, Garnier R, Pulce C, Labadie M, de Haro L, Harry P. Shiitake dermatitis recorded by French poison control centers-new case series with clinical observations. Clin Toxicol (Phila). 2014;52:625-8.

38. Wang AS, Barr KL, Jagdeo J. Shiitake mushroom-induced flagellate erythema: a striking case and review of the literature. Dermatol Online J. 2013;19(4):5.

39. Adriano AR, Acosta ML, Azulay DR, Quiroz CD, Talarico SR. Shiitake dermatitis: the first case report in Brazil. An Bras Dermatol. 2013;88:417-9.

40. Diaz-Corpas T, Mateu-Puchades A, Coll-Pulgserver MN, Marquina-Vila A. Flagellate dermatitis after eating shiitake mushrooms. Actas-Dermosifiliogr. 2011;102:830-2.

41. Haddad V Jr, Silveira FL, Migotto AE. Skin lesions in envenoming by cnidarians (Portuguese man-of-war and jellyfish): etiology and severity of accidents on the Brazilian coast. Rev Inst Med Trop Sao Paulo. 2010;52:47-50.

42. Queiroz MC, Caldas JN. Comparative dermatology: skin lesion produced by attack of jellyfishes (Physalia physalis). An Bras Dermatol. 2011;86:611-2.

43. Froudarakis M, Hatzimichael E, Kyriazopoulou L, Lagos K, Pappas P, Tzakos AG, Karavasilis V, Daliani D, Papandreou C, Briasoulis E. Revisting bleomycin from pathophysiology to safe clinical use. Clin Rev Oncol/Hematol. 2013;87:90-100.

44. Monlin G, Fiere B, Beyvin A. Cutaneous pigmentation caused by bleomycin. Bull Soc Fr Dermatol Syphiligr. 1970;77:293-6.

45. Darwish M, Bond M, Hellriegel E, Robertson P Jr, Chovan JP. Pharmacokinetic and pharmacodynamics profile of bendamustine and its metabolites. Cancer Chemother Pharmacol. 2015;75:1143-54.

46. Pazdur R, Kudelka AP, Kavanagh JJ, Cohen PR, Raber MN. The toxoids: paclitaxel (Taxol) and docetaxel (Taxotere). Cancer Treat Rev. 1993;19:351-86.

47. Ho MY, Mackey JR. Presentation and management of docetaxel $=$ related adverse effects in patients with breast cancer. Cancer Manag Res. 2014;6:253-9.

48. Marchetti MA, Noland MM, Dillon PM, Greer KE. Taxane associated subacute cutaneous lupus erythematosus. Dermatol Online J. 2013;19(8):2.
49. Carter SK, Ultmann J. Peplomycin. Cancer Treat Rev. 1984;11:303-5.

50. Meattini I, Cecchini S, Muntoni C, Scotti V, DeLuca CC, Mangoni M, Bonomo P, Nori J, Casella D, Simoncini R, Orzalesi L, Bianchi S, Livi L. Cutaneous and cardiac toxicity of concurrent trastuzumab and adjuvant breast radiotherapy: a single institution series. Med Oncol. 2014;31:891.

51. Caussa L, Kirova YM, Gault N, Pierga JY, Savignoni A, Campana F, Dendale R, Fourquet A, Bollet MA. The acute skin and heart toxicity of a concurrent association of trastuzumab and locoregional breast radiotherapy including internal mammary chain: a single-institution study. Eur J Cancer. 2011;47:65-73.

52. Smith IE. Efficacy and safety of Herceptin in women with metastatic breast cancer: results from pivotal clinical studies. Anticancer Drugs. 2001;12(suppl 4):S3-10.

53. Baselga J. Clinical trials of herceptin (trastuzumab). Eur J Cancer. 2001;37:S18-24.

54. Myskowski PL, Halpern AC. Skin reactions to the new biologic anticancer drugs. Curr Opin Support Palliat Care. 2009;3:294-9.

55. Laux I, Jain A, Singh S, Agus DB. Epidermal growth factor receptor dimerization status determines skin toxicity to HER-kinase targeted therapies. $\mathrm{Br} \mathrm{J}$ Cancer. 2006;94:85-92.

56. Adachi S, Yoshimura T, Matsuoka T, Okada K, Yasuda $\mathrm{T}$, Kamei K. Appearance of skin and nail toxicity in patients with breast cancer who underwent trastuzumab-containing chemotherapy. Gan To Kagaku Ryoho. 2011;38:1453-6.

57. Cohen AD, Mermershtain W, Geffen DB, Schoenfeld N, Mamet R, Cagnano E, Cohen Y, Halevy S. Cutaneous photosensitivity induced by paclitaxel and trastuzumab therapy associated with aberrations in the biosynthesis of porphyrins. J Dermatol Treat. 2005;16:19-21.

58. Akay BN, Unlu E, Buyukcelik A, Akyol A. Photosensitive rash in association with porphyrin biosynthesis possibly induced by docetaxel and trastuzumab therapy in a patient with metastatic breast carcinoma. Jpn J Clin Oncol. 2010;40:989-91.

59. Rosman IS, Anadkat MJ. Tufted hair folliculitis in a woman treated with trastuzumab. Target Oncol. 2010;5:295-6.

60. Beutler BD, Cohen PR. Nab-paclitaxel-associated photosensitivity: report in a woman with non-small cell lung cancer and review of taxane-related photodermatoses. Dermatol Prac Concept. 2015;5(2):121-4. 